University of Nebraska - Lincoln

DigitalCommons@University of Nebraska - Lincoln

USDA National Wildlife Research Center - Staff Publications
U.S. Department of Agriculture: Animal and Plant Health Inspection Service

September 2005

\title{
NORMAL HEMATOLOGIC AND BIOCHEMICAL VALUES FOR PRELAYING GREATER SAGE GROUSE (CENTROCERCUS UROPHASIANUS) AND THEIR INFLUENCE ON CHICK SURVIVAL
}

\author{
Mike R. Dunbar \\ USDA-APHIS-Wildlife Services, mike.r.dunbar@aphis.usda.gov \\ Michael A. Gregg \\ USFWS, Saddle Mountain National Wildlife Refuge, Richland, WA \\ John A. Crawford \\ Oregon State University \\ Mark R. Giordano \\ USFWS Sheldon/Hart Mountain National Wildlife Refuge, Lakeview, OR \\ Susan J. Tornquist \\ Oregon State University, susan.tornquist@oregonstate.edu
}

Follow this and additional works at: https://digitalcommons.unl.edu/icwdm_usdanwrc

Part of the Environmental Sciences Commons

Dunbar, Mike R.; Gregg, Michael A.; Crawford, John A.; Giordano, Mark R.; and Tornquist, Susan J., "NORMAL HEMATOLOGIC AND BIOCHEMICAL VALUES FOR PRELAYING GREATER SAGE GROUSE (CENTROCERCUS UROPHASIANUS) AND THEIR INFLUENCE ON CHICK SURVIVAL" (2005). USDA National Wildlife Research Center - Staff Publications. 10.

https://digitalcommons.unl.edu/icwdm_usdanwrc/10

This Article is brought to you for free and open access by the U.S. Department of Agriculture: Animal and Plant Health Inspection Service at DigitalCommons@University of Nebraska - Lincoln. It has been accepted for inclusion in USDA National Wildlife Research Center - Staff Publications by an authorized administrator of DigitalCommons@University of Nebraska - Lincoln. 


\title{
NORMAL HEMATOLOGIC AND BIOCHEMICAL VALUES FOR PRELAYING GREATER SAGE GROUSE (CENTROCERCUS UROPHASIANUS) AND THEIR INFLUENCE ON CHICK SURVIVAL
}

\author{
Mike R. Dunbar, M.S., D.V.M., Michael A. Gregg, M.S., John A. Crawford, Ph.D., \\ Mark R. Giordano, M.S., and Susan J. Tornquist, D.V.M., Ph.D., D.A.C.V.P.
}

\begin{abstract}
Declines in greater sage grouse (Centrocercus urophasianus) productivity and population numbers throughout their range demand a better understanding of how nutrition influences sage grouse populations. During March and April 1999-2001, blood samples were collected from 158 female (73 adult, 85 yearling), free-ranging, prelaying, greater sage grouse from an area in northwestern Nevada, USA, and southeastern Oregon, USA. These blood samples were evaluated to establish normal blood values for sage grouse and ascertain if certain blood parameters, as indices of nutrition, are useful for predicting if sage grouse hens would raise at least one chick to 1 August. Results of logistic regression indicated that three of six blood parameters analyzed-glucose, total plasma protein, and calcium : phosphorus ratio - affected the probability of a female sage grouse raising at least one chick to late summer. Ranking of the standardized estimates revealed that glucose and total plasma protein had the greatest impact on the likelihood of a female successfully raising chicks. Odds ratios indicated that a 1-unit increase in glucose $(1 \mathrm{mg} / \mathrm{dl}) \mathrm{and} \mathrm{plasma}$ protein $(0.1 \mathrm{~g} / \mathrm{dl})$ would result in a $4 \%$ and $113 \%$ positive increase, respectively, in the predicted odds of at least one chick surviving until 1 August. Odds ratios for calcium : phosphorus ratio revealed a $70 \%$ decline in the predicted odds of at least one chick surviving until 1 August if the level of this parameter increased one unit (e.g., 3:1 to 4:1). Based on these analyses, values of some blood parameters used as indices of nutrition, especially glucose, total plasma protein, and calcium : phosphorus ratio, can be successfully used to predict reproductive success of sage grouse. These parameters are not only indicative of the nutritional status of prelaying hens but may be associated with nutritional quality of the habitat and therefore have important management significance.
\end{abstract}

Key words: Centrocercus urophasianus, hematology, nutrition, sage grouse, serum.

\section{INTRODUCTION}

The greater sage grouse (Centrocercus urophasianus), a once abundant sagebrush-steppe obligate, have experienced population declines throughout much of their range over the last several decades. ${ }^{11,28}$ These declines have been attributed to degradation of sagebrush habitats (Artemisia spp.) as a result of excessive livestock grazing during the late 1800s and early 1900s, sagebrush control programs, agricultural conversions, introduction of exotic plant species, and alteration of natural fire regimes. ${ }^{7,12,15,16,28,33}$ Long-term declines in greater sage

From the U.S. Fish and Wildlife Service, Sheldon/Hart Mountain National Wildlife Refuge Complex, P.O. Box 111, Lakeview, Oregon 97630, USA (Dunbar, Gregg, Giordano), the Department of Fisheries and Wildlife, Oregon State University, Corvallis, Oregon 97331, USA (Crawford), and the Department of Biomedical Sciences, Oregon State University, Corvallis, Oregon 97331, USA (Tornquist). Present addresses (Dunbar): USDA/APHIS/ WS, National Wildlife Research Center, 4101 LaPorte Avenue, Fort Collins, Colorado 80521, USA; (Gregg): U.S. Fish and Wildlife Service, Hanford Reach National Monument and Saddle Mountain National Wildlife Refuge, 3250 Port of Benton Boulevard, Richland, Washington 99352, USA. Correspondence should be addressed to Dr. Dunbar. grouse abundance in Nevada and Oregon have been attributed to reduced sage grouse productivity. ${ }^{12,29}$

Several studies identified that nutritional variation in wild breeding bird populations was a critical factor affecting reproductive success. ${ }^{9,30,31,36,37}$ Poor productivity in some tetraonids may be caused by inadequate nutrition of hens during the breeding (prelaying) season. ${ }^{6,37}$ Female red grouse (Lagopus lagopus scoticus) and ruffed grouse (Bonasa umbellus) that obtained adequate nutrition in spring diets contributed more nutrients to eggs ${ }^{6,37}$ and produced larger clutches and larger, more viable chicks than did hens on less nutritious diets. ${ }^{6,17,26}$ Captive willow ptarmigan (Lagopus lagopus lagopus) hens fed a low-protein diet produced chicks with lower survivability than chicks from other groups. ${ }^{23}$ It has been reported that nitrogen (protein) and phosphorus (P) were the most important nutrients for red grouse in the spring before egg laying. ${ }^{34,35}$ Evidence has also been presented not only that hen nutrition may influence egg quality but that hen nutrition and egg quality influenced chick survival.6,37

Declines in sage grouse productivity and population numbers throughout their range necessitate a better understanding of how nutrition influences sage grouse populations. In addition to data on population dynamics and habitat analyses, physiologi- 
cal parameters, including blood values, especially those that relate to nutritional condition, may provide important information for evaluating the response of an animal to its environment and provide important diagnostic information related to animal health and nutrition. ${ }^{8,43}$ Normal values for hematology and selected biochemical parameters may also provide insight into differences in habitat components as potential limiting factors and a means for quantitative assessment of the nutritional adequacy of the habitat. ${ }^{43}$ Consequently, blood values may then be used to evaluate the collective effects of both environmental factors and land management practices (e.g., livestock grazing, rangeland fire) on wildlife.

Objectives of this study were to establish normal blood values for sage grouse and examine if certain blood parameters, as indices of nutrition, are useful for predicting if sage grouse hens would raise at least one chick to 1 August.

\section{MATERIALS AND METHODS}

Greater sage grouse were sampled from northwestern Nevada (USA) and southeastern Oregon (USA) on lands administered by the U.S. Fish and Wildlife Service and Bureau of Land Management. Prelaying greater sage grouse were captured on or near leks during mid-March to mid-April, 19992001 using the spotlight-netting technique. ${ }^{21}$ Sex and age of captured birds were determined from wing-molt and plumage characteristics. ${ }^{5,14,38}$

Birds were restrained by hand, and approximately $0.75-1.5 \mathrm{ml}$ of blood was collected by venipuncture of the brachial vein. Blood samples for serum chemistries were collected into Microtainer ${ }^{\circledR}$ serum separator tubes (Becton Dickinson and Company, Franklin Lakes, New Jersey 07417, USA) and kept at cold, but not freezing, temperatures, for 1-6 hr. Samples were then centrifuged at 3,000 to $3,500 \mathrm{rpm}$, and the serum was extracted and aliquoted into plastic screw-cap tubes (Sarstedt Incorporated, Newton, North Carolina 28658, USA). Samples for complete blood cell counts (CBC) and total plasma protein (TPP) were collected into Microtainer ${ }^{\circledR}$ EDTA tubes. All samples were refrigerated for 8-36 hr until overnight shipment to the laboratory for analysis. Blood smears on glass slides were made from fresh blood for white blood cell (WBC) differential counts.

Samples were analyzed at the Veterinary Diagnostic Laboratory, College of Veterinary Medicine, Oregon State University, Corvallis, Oregon, 97331 USA. Serum biochemistries (uric acid, UA; calcium, Ca; P; creatine kinase, CK; aspartate aminotransferase, AST; blood urea nitrogen, BUN; glu- cose; and albumin) were performed on an automated chemistry analyzer (Hitachi 717 Biochemical Analyzer, Roche/Boehringer Manheim, Indianapolis, Indiana 46201, USA) using standard reagents and methods. Packed cell volumes (PCV) were measured by the standard capillary tube method after centrifugation of a microhematocrit tube. Total plasma proteins were determined by refractometer. Total WBC counts were performed by use of either an eosinophil unopette chamber (Unopette 5877, Becton-Dickinson, Cockeysville, Maryland, 21030 USA) or estimated from a blood smear at $\times 40$ magnification. Fields of uniform distribution of erythrocytes were then used to count leukocytes found in a uniform monolayer. An average leucocyte count from 10 fields was multiplied by 2,000 to get the WBC estimate per microliter. ${ }^{41}$

To determine reproductive status, each hen was fitted with a numbered aluminum leg band and 20g necklace-mounted radio transmitters (Advanced Telemetry Systems, Isanti, Minnesota 55040, USA) and monitored, beginning in April, approximately once every 3 days. Nests were located and monitored to determine fate. Nests were classified as successful if at least one egg hatched, determined by detachment of the eggshell membrane. Hens that nested successfully were monitored to determine brood-rearing success. All hens that successfully nested were flushed between mid-July and $1 \mathrm{Au}-$ gust and were considered successful if they had at least one chick.

A mean date of 1 May (range 26 April to 4 May) of the conclusion of egg laying (start of incubation) for the birds in our sample was established based on estimated hatch dates of 1,041 juvenile sage grouse wings obtained during late summer 19992001 from hunters in southeastern Oregon. ${ }^{13}$ Wing plumage characteristics were used to estimate hatching dates..$^{39}$ Based on other studies ${ }^{13}$ and our extensive work conducted within the study area, we used an incubation time of 28 days. Because we collected blood samples from hens as late as midApril, some hens in the study area could potentially have begun egg laying. However, no hens in our sample were observed egg laying. Our earliest observation of egg laying in our sample of hens was approximately $2 \mathrm{wk}$ after the date of sample collection. This information, concerning dates of egg laying, was used in the evaluation of some blood parameters, especially $\mathrm{Ca}$ and $\mathrm{P}$, that can be influenced by physiological changes that occur as a bird approaches time of egg-laying.

To establish reference intervals, sample means and standard deviations were estimated for each serum chemistry, total plasma protein, and hemato- 
Table 1. Mean ( \pm SD) and sample size of total plasma protein, serum chemistry, and hematologic values of prelaying, female greater sage grouse in northwestern Nevada and southeastern Oregon, 1999-2001.

\begin{tabular}{|c|c|c|c|}
\hline Parameter & Units & $n$ & Mean \\
\hline Albumin & $\mathrm{g} / 1$ (g/dL) & 143 & $21.00 \pm 2.00(2.1 \pm 0.2)$ \\
\hline Total plasma protein & $\mathrm{g} / \mathrm{L}(\mathrm{g} / \mathrm{dL})$ & 138 & $53.00 \pm 12.00(5.3 \pm 1.2)$ \\
\hline Calcium & $\mathrm{mmol} / \mathrm{L}(\mathrm{mg} / \mathrm{dL})$ & 141 & $5.35 \pm 1.85(21.4 \pm 7.4)$ \\
\hline Phosphorus & $\mathrm{mmol} / \mathrm{L}(\mathrm{mg} / \mathrm{dL})$ & 144 & $2.35 \pm 0.77(7.3 \pm 2.4)$ \\
\hline Calcium: Phosphorus ratio & & 141 & $3.0 \pm 0.60$ \\
\hline Glucose & mmol/L (mg/dL) & 144 & $17.61 \pm 1.90(320.2 \pm 34.6)$ \\
\hline Blood urea nitrogen & $\mathrm{mmol} / \mathrm{L}(\mathrm{mg} / \mathrm{dL})$ & 102 & $1.28 \pm 3.28(1.8 \pm 4.6)$ \\
\hline Uric acid & $\mathrm{mmol} / \mathrm{L}(\mathrm{mg} / \mathrm{dL})$ & 143 & $0.31 \pm 0.12(5.4 \pm 2.2)$ \\
\hline Creatine kinase & $\mathrm{U} / \mathrm{L}$ & 143 & $2395.9 \pm 1017.1$ \\
\hline Aspartate aminotransferase & $\mathrm{U} / \mathrm{L}$ & 144 & $430.3 \pm 77.2$ \\
\hline Packed cell volume & $\%$ & 119 & $53 \pm 8$ \\
\hline White blood cell count & cells/ $\mu \mathrm{L}$ & 151 & $5539 \pm 1918$ \\
\hline Heterophil & cells/ $\mu \mathrm{L}$ & 151 & $2048 \pm 1250$ \\
\hline Heterophil & $\%$ & 151 & $36 \pm 16$ \\
\hline Lymphocyte & cells $/ \mu \mathrm{L}$ & 151 & $3376 \pm 1370$ \\
\hline Lymphocyte & $\%$ & 151 & $62 \pm 16$ \\
\hline Monocyte & cells/ $\mu \mathrm{L}$ & 145 & $50 \pm 123$ \\
\hline Monocyte & $\%$ & 151 & $1 \pm 2$ \\
\hline Basophil & cells/ $\mu \mathrm{L}$ & 148 & $44 \pm 127$ \\
\hline Basophil & $\%$ & 151 & $1 \pm 2$ \\
\hline Eosinophil & cells/ $\mu \mathrm{L}$ & 118 & $11 \pm 36$ \\
\hline Eosinophil & $\%$ & 118 & $0.2 \pm 1$ \\
\hline
\end{tabular}

logic parameter. Data were pooled across years to facilitate comparison with other studies. Parameter means were compared between age classes (adult and yearling) with $90 \%$ confidence intervals.

We evaluated the effects of six parameters (TPP, albumin, $\mathrm{Ca}: \mathrm{P}$, glucose, UA, and PCV) on the probability of hens recruiting at least one chick to late summer using logistic regression (PROC LOGISTIC; LR). We selected these parameters because they likely reflect the nutritional condition of birds, were important for reproduction in other avian species, and are not usually affected by capture and minimal handling. Before we conducted our analysis, we tested for multicollinearity among variables (PROC CORR and PROC REG). We found a significant relationship between $\mathrm{Ca}$ and $\mathrm{P}\left(r^{2}=\right.$ $0.74, P<0.0001)$. Because these variables are important for reproduction in birds, we calculated the $\mathrm{Ca}: \mathrm{P}$ ratio for each hen to create a new variable, which was used in the LR analysis. Initially, we used a goodness-of-fit test ${ }^{25}$ to determine if our model fit the data. To determine the effect of each variable on the probability of a hen raising a chick to late summer, we calculated odds ratios and ranked variables using standardized parameter estimates $(|\beta| / \mathrm{SE}[\beta])$. The maximum rescaled $R^{2}$ was used to determine predictive power of the regression model. ${ }^{1}$ Only the hens that initiated nests and survived until at least 1 August of the year they were captured were included in the analysis. All analyses were performed in SAS (Statistical Analysis System, Version 8.2, Cary, North Carolina, 27511 USA) and tests were significant at $\alpha=0.05$.

\section{RESULTS}

We captured 158 (73 adults, 85 yearlings) prelaying hens. No parameter means were different between age classes based on $90 \%$ confidence intervals. Mean values for serum chemistry, TPP, and hematology can be found in Table 1. Calcium levels increased over the capture period (Fig. 1) based on $90 \%$ confidence intervals. The increase was apparent 6 weeks before egg laying and more noticeable after the fifth week (Fig. 1).

Of the 158 hens we captured, 69 were included in the LR analysis. Our model adequately fit the data $\left(\chi^{2}=14.01\right.$, df $\left.=8, P=0.08\right)$. Results indicated that three of the six blood parameters in the model affected the probability of a female sage grouse raising at least one chick to late summer (Table 2). However, predictive power of the model was low $\left(R^{2}=0.34\right)$. Ranking of the standardized estimates revealed that glucose and TPP had the greatest impact on the likelihood of a female successfully raising chicks (Table 3 ). Odds ratios indicated that a 1-unit increase in glucose $(1 \mathrm{mg} / \mathrm{dl})$ 


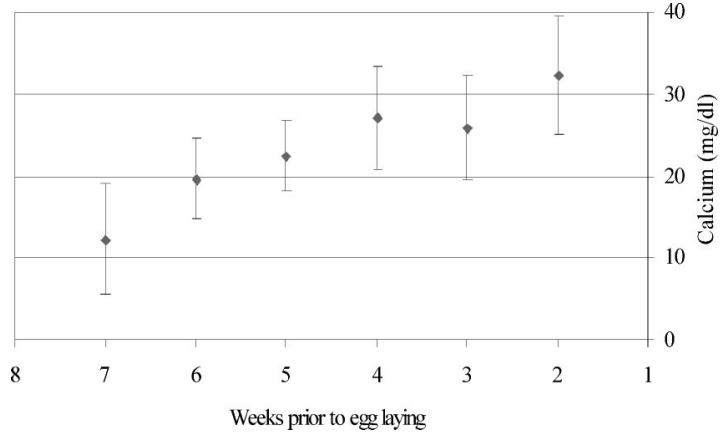

Figure 1. Weekly mean total serum calcium levels, 2 to $7 \mathrm{wk}$ before egg laying, for greater sage grouse hens (Centrocercus urophasianus) captured in northwestern Nevada and southeastern Oregon, 1999-2001.

and plasma protein $(0.1 \mathrm{~g} / \mathrm{dl})$ would result in a $4 \%$ and $113 \%$ positive increase, respectively, in the predicted odds of at least one chick surviving until 1 August (Table 3). Odds ratios for $\mathrm{Ca}: \mathrm{P}$ ratio revealed a $70 \%$ decline in the predicted odds of at least one chick surviving until 1 August if the level of this parameter increased 1 unit (Table 3), (e.g., $3: 1$ to $4: 1$ ). Although there were no significant differences in $\mathrm{Ca}: \mathrm{P}$ ratios during the capture period, some hens had ratios that approached 4:1 (Fig. 2). Based on the odds ratio, this value may not be conducive to production of chicks and probably represents inadequate $\mathrm{P}$ in the diet.

\section{DISCUSSION}

Although some sage grouse appeared thin on capture, on clinical examination no birds in our study exhibited clinical signs of disease, which could have affected blood values. Examination of some blood values indicated that the birds were not ill or diseased. All birds in this study were apparently healthy enough to successfully nest. This would suggest that they were not in poor health at capture. The field conditions in which the samples were collected and stored may have had some in- fluence on some of our reported blood values. Blood clotting times of 1-6 hr and storage of samples in refrigeration for $8-36 \mathrm{hr}$ before being sent to the laboratory are legitimate concerns relating to sample integrity. However, field conditions necessitated these methods. We believe these issues had minor influence on the results because prolonged blood clotting times at low temperatures have much less effect on some blood parameters, including glucose, than at room temperatures. Our samples were kept at low, but not freezing, temperatures during and after clotting. Also, some blood parameters, including glucose, remain relatively stable after serum is separated and stored under refrigeration. Our model indicated that blood parameters used to assess nutritional condition of the prelaying hen, especially glucose, TPP, and Ca : P ratios were important predictors of chick survival to 1 August.

Glucose is the simplest but most important and available source of energy for a bird, and blood glucose is an indicator of nutritional condition. In the very early stages of incubation, the developing embryo uses glucose as a primary source of energy. ${ }^{45}$ Normal values for blood glucose in most species of birds usually range from 11 to $27.5 \mathrm{mmol} /$ L (200-500 mg/dl). ${ }^{24}$ Typically, caged aviary birds will have glucose levels near $16.5 \mathrm{mmol} / \mathrm{L}$ (300 $\mathrm{mg} / \mathrm{dl}) .{ }^{19}$ Severe hypoglycemia $<8.25 \mathrm{mmol} / \mathrm{L}$ (150 $\mathrm{mg} / \mathrm{dl}$ ) indicates a grave condition and can be life threatening. ${ }^{2}$ We found only two birds that had $<13.75 \mathrm{mmol} / \mathrm{L}(250 \mathrm{mg} / \mathrm{dl})$ of blood glucose. In addition to malnourishment, low blood glucose values in birds may result from hepatopathies, septicemia, and endocrinopathies. ${ }^{46}$ However, no birds in our study showed clinical signs of any of these diseases. Evaluation of blood parameters revealed that no birds were ill or diseased. Low blood glucose levels may also result from prolonged blood clotting times. Low glucose concentrations in some of our samples may have been caused by clotting times that ranged from 1 to $6 \mathrm{hr}$, which was necessary because of field conditions. However, these

Table 2. Parameter estimates from the logistic regression model for blood parameters that may be useful for predicting likelihood of female prelaying greater sage grouse raising at least one chick to 1 August in northwestern Nevada and southeastern Oregon, 1999-2001.

\begin{tabular}{lcccc}
\hline \multicolumn{1}{c}{ Parameter } & Estimate & SE & $\chi^{2}$ & $P$ \\
\hline Total plasma protein & 0.75 & 0.33 & 5.33 & 0.02 \\
Albumin & 2.80 & 1.52 & 3.39 & 0.07 \\
Calcium : Phosphorus ratio & -1.20 & 0.60 & 4.00 & 0.05 \\
Glucose & 0.04 & 0.01 & 9.08 & 0.002 \\
Uric acid & -0.24 & 0.17 & 2.07 & 0.15 \\
Packed cell volume & -0.05 & 0.05 & 1.04 & 0.31 \\
\hline
\end{tabular}


Table 3. Standardized parameter estimates, odds ratio, and $95 \%$ confidence intervals of odds ratios for blood parameters that may be useful for predicting likelihood of female prelaying greater sage grouse raising at least one chick to 1 August in northwestern Nevada and southeastern Oregon, 1999-2001.

\begin{tabular}{lccc}
\hline \multicolumn{1}{c}{ Parameter (units) } & Standardized estimate & Odds ratio & $95 \%$ CI \\
\hline Glucose (mmol/L) & 4.00 & 1.04 & $1.01-1.06$ \\
Total plasma protein (g/L) & 2.27 & 2.13 & $1.12-4.04$ \\
Calcium : phosphorus & & & $0.09-0.98$ \\
$\quad$ (ratio) & 2.00 & 0.30 & $0.84-324.23$ \\
Albumin (g/L) & 1.84 & 16.47 & $0.56-1.09$ \\
Uric acid (mmol/L) & 1.40 & 0.78 & $0.87-1.04$ \\
Packed cell volume $(\%)$ & 1.00 & 0.96 & \\
\hline
\end{tabular}

blood samples were stored at low temperatures in the field until they were processed, which may have kept glucose concentrations from falling.

Hyperglycemia can occur in birds undergoing acute stress. ${ }^{2,46}$ Because our birds were wild-caught, capture may have provided this stressor, which would have influenced the model. However, in mammals, this increase may not become apparent for 10-45 min of handling. ${ }^{43}$ We handled most birds for $\leq 10 \mathrm{~min}$. Hyperglycemia in birds may result in glucose levels of $24.75-33.00 \mathrm{mmol} / \mathrm{L}$ (450-600 mg/dl). ${ }^{46}$ Only one hen from our sample had a glucose level $>24.75 \mathrm{mmol} / \mathrm{L}(450 \mathrm{mg} / \mathrm{dl})$, and only two others had glucose levels $>22.00$ $\mathrm{mmol} / \mathrm{L}(400 \mathrm{mg} / \mathrm{dl})$. Therefore, it does not appear that capture-induced hyperglycemia influenced model results. Some increase in blood glucose levels, as our model indicated, would likely be beneficial to egg-laying birds, as it may provide more energy to meet the demands of egg formation and laying. This may result in higher quality eggs that would increase chick survivability. ${ }^{6,37}$

Total plasma protein is considered an index of dietary protein, ${ }^{3}$ although blood protein levels in some species of birds can be influenced by hormones, including estrogen, during development of

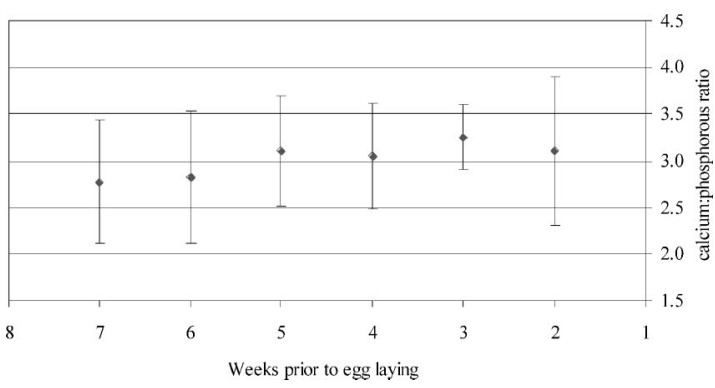

Figure 2. Weekly mean calcium : phosphorus ratios, 2 to $7 \mathrm{wk}$ before egg laying, for greater sage grouse hens (Centrocercus urophasianus) captured in northwestern Nevada and southeastern Oregon, 1999-2001. follicles. ${ }^{9}$ It has been reported that protein requirements for egg laying are physiologically more important than energy in many birds. ${ }^{40}$ Total plasma protein levels are important to the hen all year but are critical during egg-laying. In one study, captive red grouse hens started to increase their feed intake 5 weeks before laying, and it was suggested that both fertility and hatchability might be improved if protein-rich breeding diets were given from that time to egg-laying. ${ }^{42}$ Dietary protein also appears to influence chick survival in red and ruffed grouse. ${ }^{6,37}$ A deficiency of protein in birds usually results in an increase in the calorie : protein ratio, which in turn can result in a reduction of egg production or growth of the chick. ${ }^{18}$ Mean TPP values during the spring in several species of nonlaying adult Galliformes were found to range from 35.0 to $49.0 \mathrm{~g} / \mathrm{L}(3.5-4.9 \mathrm{~g} / \mathrm{dl}) .{ }^{4} \mathrm{In}$ general, TPP values in birds range from 35.0 to $60.0 \mathrm{~g} / \mathrm{L}(3.5-6.0 \mathrm{~g} / \mathrm{dl})$, and birds with TPP levels below $35 \mathrm{~g} / \mathrm{L}(3.5 \mathrm{~g} / \mathrm{dl})$ would have less chance of recovery from illness than birds with higher TPP levels. ${ }^{3}$ Therefore, birds from our sample with a TPP value $\leq 35 \mathrm{~g} / \mathrm{L}(3.5 \mathrm{~g} /$ dl) could have been considered to have nutritional deficiencies. However, we found only three birds in our study that had TPP values $\leq 35 \mathrm{~g} / \mathrm{L}(3.5 \mathrm{~g} / \mathrm{dl})$.

Total plasma protein concentrations may be decreased as a result of decreased concentrations of albumin or globulins. Low TPP may reduce the amount of protein the hen is able to supply the egg. Albumin serves as a major reservoir for protein and acts as a transport carrier for vitamins, minerals, hormones, and fatty acids. ${ }^{10}$ Low TPP may also result in a possible negative impact on the hen's ability to mobilize $\mathrm{Ca}$ and $\mathrm{P}$, elements crucial for shell production and skeletal formation of the embryo., ${ }^{9,10}$ Low TPP levels may also reduce the hen's ability to balance the $\mathrm{Ca}: \mathrm{P}$ ratio. Some protein fractions are involved in immune responses, transport, and blood clotting ${ }^{2}$; therefore, low levels of these components could lead to immune system deficiencies, 
which could affect chick survival. Plasma protein values can also increase during acute illness through an increase in immunoglobulins ${ }^{19}$ or decrease from chronic illness. ${ }^{3}$ However, on clinical evaluation at capture and evaluation of individual blood parameters, no birds appeared diseased or ill. Increases in dietary protein would likely improve the chances of chick survival, as indicated by our model. The finding in our study that total plasma protein influences chick survival supports findings by others. ${ }^{6,37}$

The mean Ca level in this study was $5.35 \pm 1.85$ $\mathrm{mmol} / \mathrm{L}(21.4 \pm 7.4 \mathrm{mg} / \mathrm{dl})$, higher than normal values in other species of birds, which average $2.00-3.75 \mathrm{mmol} / \mathrm{L}(8.0-15.0 \mathrm{mg} / \mathrm{dl}) .^{24}$ It is likely that the higher levels of $\mathrm{Ca}$ in birds in this study compared to that in other avian species results from birds in our study approaching egg laying. According to other researchers, an estrogen-induced increase in Ca levels may occur during time of egg laying, just preceding egg laying, or during ovulation. ${ }^{9,32}$ Hens in this study may have been captured over such a time that this increase was observed (Fig. 1). Future research should take these differences into account, as they may influence how data on blood values are analyzed and interpreted. Therefore, we suggest an effort be made to capture birds as close together, temporally, and as close to the initiation of egg laying, as possible.

The mean $\mathrm{P}$ value in this study was $2.35 \pm 0.77$ $\mathrm{mmol} / \mathrm{L}(7.3 \pm 2.4 \mathrm{mg} / \mathrm{dl})$ and appears relatively high in comparison to values from captive Gruiformes, Anseriformes, Falconiformes, and other Galliformes, whose mean $\mathrm{P}$ values range from $0.71 \pm$ $0.29 \mathrm{mmol} / \mathrm{L}(2.2 \pm 0.9 \mathrm{mg} / \mathrm{dl})$ to $1.55 \pm 0.19$ $\mathrm{mmol} / \mathrm{L}(4.8 \pm 0.6 \mathrm{mg} / \mathrm{dl}){ }^{20}$ Phosphorus levels increase when birds approach egg laying, ${ }^{22}$ which likely accounts for the increase in $\mathrm{P}$ values in birds in this study. However, values for $\mathrm{P}$ in some birds in this study may not be within normal values for hens approaching egg laying because some hens had $\mathrm{Ca}: \mathrm{P}$ ratios that exceeded 3:1, some nearly 4 : 1. Low $P$ values in hens were likely the reason for the higher ratios above $3: 1$. The $\mathrm{Ca}: \mathrm{P}$ ratio is not as easy to interpret as $\mathrm{Ca}$ and $\mathrm{P}$ individually. The $\mathrm{Ca}: \mathrm{P}$ ratio is a useful indicator because it is not just the levels of the individual parameters that are important. ${ }^{10}$ Too much or too little of either element can lead to decreased egg production and can affect the uptake and use of the other.

Overall, we found some blood parameters used in the LR analysis to be useful predictors of whether hens raised at least one chick to 1 August, but predictive ability was low. This was not unexpected, however. Because the embryo receives all the nutrients it needs from the hen, it is perhaps intuitive that the nutrition of the hen influences egg quality and, therefore, chick survival to some extent. If the hen is deficient in nutrients important to the egg and chick, survival of the chicks may be reduced. Although it is not clear whether sage grouse rely totally on spring diet for clutch formation and egg quality, as do some other Galliformes, ${ }^{44}$ or on a combination of spring diet and endogenous nutrient reserves, the examination of some blood parameters during prelaying may provide important information on the nutritional condition of the hen during that time. Additionally, other factors not measured in this study may have influenced chick survival to 1 August, including brood-rearing habitat, predation, disease, and environmental conditions. However, even with the possible influence of these other factors, nutrition of the prelaying hen, according to our model, does exert an influence on chick survival until late summer.

The use of hematologic and biochemical parameters can have important diagnostic value when evaluating sage grouse health and condition, especially as they may relate to chick survival. However, long-term studies will be necessary to evaluate physiologic indices over the entire range and distribution of sage grouse to augment the reliability of physiologic data as an indicator of the health or condition of sage grouse populations and to expand its application in sage grouse management. These values could provide important information relating to effects of existing and changing land management practices, including livestock grazing, effects of rangeland fire, and other habitat alterations on sage grouse health and condition.

Acknowledgments: We appreciate the many biologists, graduate students of Oregon State University, technicians, and volunteers who spent long hours on cold nights collecting data for this project. Logistic support for some portions of the study area was generously provided by the Bureau of Land Management and from the Beaty's Butte Grazing Association. Financial support was provided by U.S. Fish and Wildlife Service, Bureau of Land Management, Oregon Department of Fish and Wildlife, Nevada Division of Wildlife, National Fish and Wildlife Foundation, Nevada Bighorns Unlimited, and Nevada Chukar Foundation.

\section{LITERATURE CITED}

1. Allison, P. D. 1999. Logistic Regression Using the SAS System: Theory and Application. SAS Institute, Inc., Cary, North Carolina. 
2. Altman, R. B., S. L. Clubb, G. M. Dorrestein, and K. Quesenberry. 1997. Avian clinical pathology-hematology and chemistry. In: Altman, R. B. (ed.). Avian Medicine and Surgery, 1st ed. W. B. Saunders Co., Philadelphia, Pennsylvania. Pp. 149-157.

3. Amand, W. B. 1986. Avian clinical hematology and blood chemistry. In: Fowler, M. E. (ed.). Zoo and Wild Animal Medicine, 2nd ed. W. B. Saunders Co., Philadelphia, Pennsylvania. Pp. 264-276.

4. Balasch, J., L. Palacios, S. Musquera, J. Palomeque, M. Jimenez, and M. Alemany. 1973. Comparative hematological values of several Galliformes. Poultry Sci. 52: 531-534.

5. Beck, T. D., R. B. Gill, and C. E. Braun. 1975. Sex and age determination of sage grouse from wing characteristics. Game Information Leaflet \#49 (revised). Colorado Division of Wildlife, Fort Collins, Colorado.

6. Beckerton, P. R., and A. L. A. Middelton. 1982. Effects of dietary protein levels on ruffed grouse reproduction. J. Wildl. Manage. 46: 569-579.

7. Braun, C. E., T. Brill, and R. O. Wallestad. 1977. Guidelines for maintenance of sage grouse habitats. Wildl. Soc. Bull. 5: 99-106.

8. Campbell, T. W. 1994. Hematology. In: Ritchie, B. W., and G. J. Harrison (eds.). Avian Medicine, Principles and Application, Wingers Publishing, Lake Worth, Florida. Pp. 176-198.

9. Carey, C. 1996. Female reproductive energetics. In: Carey, C. (ed.). Avian Energetics and Nutritional Ecology, Chapman Hall, International, Thomson Publishing, New York, New York. Pp. 324-374.

10. Carlson, G. P. 1996. Clinical chemistry tests. In: Smith, B. P. (ed.). Large Animal Internal Medicine, Diseases of Horses, Cattle, Sheep, and Goats. 2nd ed. Mosby, Inc., St. Louis, Missouri. Pp. 441-470.

11. Connelly, J. W., and C. E. Braun. 1997. Long-term changes in sage grouse (Centrocercus urophasianus) populations in Western North America. Wildl. Biol. 3/4: 123128.

12. Crawford, J. A., and R. S. Lutz. 1985. Sage grouse population trends in Oregon, 1941-1983. Murrelet 66: 69-74.

13. Crawford, J. A., N. Swanson, and M. Pope. 2002. Oregon grouse harvest report 2001. 2001 annual report. Game bird research program. Oregon State University, Corvallis, Oregon.

14. Crunden, C. W. 1963. Age and sex of sage grouse from wings. J. Wildl. Manage. 27: 846-850.

15. Dalke, P. D., D. B. Pyrah, D. C. Stanton, J. E. Crawford, and E. F. Schlatterer. 1963. Ecology, productivity, and management of sage grouse in Idaho. J. Wildl. Manage. 27: 811-841.

16. Drut, M. S. 1994. Status of sage grouse with emphasis on populations in Oregon and Washington. Audubon Society of Portland, Portland, Oregon.

17. Eastman, D. S., and D. Jenkins. 1970. Comparative food habits of red grouse in northeast Scotland, using fecal analysis. J. Wildl. Manage. 34: 612-620.

18. Fraser, C. M. 1986. Nutrition and management: poultry. In: The Merck Veterinary Manual, 6th ed. Merck \& Co., Inc. Rahway, New Jersey. Pp. 1188-1210.

19. Fudge, A. M. 1996. Avian clinical biochemistry. In: Rosskopf, W. J., and R. W. Woerpel (eds.). Diseases of Cage and Aviary Birds, 3rd ed. Williams and Wilkins, Baltimore, Maryland. Pp. 774-782.

20. Gee, G. F., J. W. Carpenter, and D. G. L. Hensler. 1981. Species differences in hematological values of captive cranes, geese, raptors, and quail. J. Wildl. Manage. 45: 463-483.

21. Giesen, K. M., T. J. Schoenberg, and C. E. Braun. 1982. Methods for trapping sage grouse in Colorado. Wildl. Soc. Bull. 10: 224-231.

22. Greenberg, D. M., C. E. Larson, P. B. Pearson, and B. R. Burmester. 1936. The state and partition of the calcium and inorganic phosphorus in the serum of the fowl. Effect of growth and ovulation. Poultry Sci. 15: 483-489.

23. Hanssen, I., J. Ness, and J. B. Steen. 1982. Parental nutrition and chick production in captive willow ptarmigan (Lagopus lagopus lagopus). Acta Veterinaria Scandinavica 23: 528-538.

24. Harris, D. J. 1991. Laboratory testing in pet avian medicine. In: Rosskopf, W. J., and R. W. Woerpel (eds.). The Veterinary Clinics of North America, W. B. Saunders Co., Philadelphia, Pennsylvania. 21: 1147-1156.

25. Hosmer, D. W., and S. Lemoshow. 1989. Applied Logistic Regression. John Wiley \& Sons, New York, New York.

26. Jenkins, D., A. Watson, and G. R. Miller. 1963. Population studies on red grouse (Lagopus lagopus scoticus) (Lath.) in north-east Scotland. J. Anim. Ecol. 32: 317-376.

27. Jenkins, D., A. Watson, and N. Picozzi. 1965. Red grouse chick survival in captivity and in the wild. Transactions of the VI Congress International Union Game Biology. Pp. 63-70.

28. Johnsgard, P. A. 1983. The Grouse of the World. University of Nebraska Press, Lincoln, Nebraska.

29. Klebenow, D. A. 1985. Habitat management for sage grouse in Nevada. World Pheasant Assoc. J. 10: 3446.

30. Lack, K, D. 1966. Population Studies of Birds. Oxford University Press, Oxford, United Kingdom.

31. Lack, K. D. 1968. Ecological Adaptations for Breeding in Birds. Chapman and Hall, Ltd. London, United Kingdom.

32. Lewandowski, A. H., T. W. Campbell, and G. H. Harrison. 1986. Clinical chemistries. In: Harrison, G. J., and L. R. Harriston (eds.). Clinical Avian Medicine and Surgery, W. B. Saunders Co., Philadelphia, Pennsylvania. Pp. 192-200.

33. Martin, R. C. 1990. Sage grouse responses to wildfire in spring and summer habitats. M.S. thesis. University of Idaho, Moscow, Idaho.

34. Moss, R. 1967. Probable limiting nutrients in the main food of red grouse (Lagopus lagopus scoticus). In: Petrusewicz, K. (ed.). Secondary Productivity of Terrestrial Ecosystems. 2 vols. Panstwowe Wydawnictwo Naukowe, Warszawa and Krakow, Poland. Pp. 369-379.

35. Moss, R. 1972. Food selection by red grouse ( $\mathrm{La}$ - 
gopus lagopus scoticus) in relation to chemical composition. J. Anim. Ecol. 41: 411-428.

36. Moss, R. and A. Watson. 1974. A role of nutrition in the population dynamics of some game birds (Tetaonidae). Trans. Int. Cong. Game Biol. 10: 193-201.

37. Moss, R., A. Watson, and R. Parr. 1975. Maternal nutrition and breeding success in red grouse (Lagopus lagopus scoticus). J. Anim. Ecol. 44: 233-244.

38. Ottomeier, A. A., and J. A. Crawford. 1996. Revised measurements of classification of age of sage grouse from wings. California Fish and Game 82: 61-65.

39. Pyrah, D. B. 1963. Sage grouse investigations. Idaho Department of Fish and Game, Boise, Idaho. P-R Project W-125-R-2.

40. Robbins, C. T. 1983. Wildlife Feeding and Nutrition. Academic Press, Inc, New York, New York.

41. Russo, E. A., L. McEntee, L. Applegate, and J. S. Baker. 1986. Comparison of two methods for determination of white blood cell counts in macaws. J. Am. Vet. Med. Assoc. 189: 1013-1016.

42. Savory, C. J. 1975. Seasonal variations in the food intake of captive red grouse. Br. Poul. Sci. 16: 471-479.

43. Seal, U. S. 1978. Assessment of habitat condition by measurement of biochemical and endocrine indicators of the nutritional, reproductive, and disease status of freeranging animal populations. In: Proceedings of the Symposium Classification, Inventory, and Analyses of Fish and Wildlife Habitat. U.S. Department of the Interior, U.S. Fish and Wildlife Service, Office of Biological Services. Washington D.C. Pp. 305-329.

44. Thomas, V. G. 1986. Body conditions, ovarian hierarchies, and their relation to egg formation in Anseriform and Galliform species. In: Quellet, H. (ed.), Acta XIX Congressus Internationalis Ortnithologici, National Museum of Natural Sciences, University of Ottawa Press, Ottawa, Canada. Pp. 353-363.

45. Vleck, C. M., and D. Vleck. 1996. Embryonic energetics. In: Carey, C. (ed.). Avian Energetics and Nutritional Ecology. Chapman and Hall, New York, New York.

46. Woerpel, R. W., and W. J. Rosskopf. 1984. Clinical experience with avian laboratory diagnostics. In: Harrison, G. J. (ed.). The Veterinary Clinics of North America: Small Animal Practice. W.B. Saunders Company, Philadelphia, Pennsylvania. Pp. 249-286.

Received for publication 6 August 2004 